\title{
HUBUNGAN KESELAMATAN DAN KESEHATAN KERJA (K3) DENGAN KINERJA KARYAWAN PADA PT. UOB INDONESIA CABANG BENGKULU
}

\author{
Ida Ayu Er. Meytha Gayatri \\ Program Studi Manajemen \\ Fakultas Ekonomi Universitas Dehasen Bengkulu
}

\begin{abstract}
Ida Ayu Er. Meytha Gayatri: Tujuan penelitian ini adalah untuk mengetahui hubungan Keselamatan dan Kesehatan Kerja (K3) tempat. kinerja karyawan di cabang PT. UOB Indonesia Cabang Bengkulu. Dari hasil perhitungan analisis koefisien korelasi Spearman rank dari jumlah 0,89 atau rho di 0,80-1,000 yang sangat kuat, yang berarti bahwa hubungan antara variabel Kesehatan dan Keselamatan Kerja (K3) dengan kinerja karyawan PT. UOB Indonesia Cabang Bengkulu berhubungan sangat kuat. Pengujian hipotesis hasil, $t$ hitung dari 14,863 dan t tabel adalah 2,0003 atau $(14,863>2,0003)$, maka Ho ditolak dan Ha diterima berarti ada hubungan yang signifikan antara keselamatan dan kesehatan kerja (K3) dengan kinerja karyawan di PT. Cabang UOB Indonesia Cabang Bengkulu.
\end{abstract}

\begin{abstract}
Ida Ayu Er. Meytha Gayatri; The purpose of this study was to determine the relationship of Occupational Health and Safety (K3) place. the performance of employees in the branch of PT. UOB Indonesia Bengkulu Branch. From the calculation of the Spearman rank correlation coefficient analysis of the amount of 0.89 or 0.80 to 1.000 rho in a very strong, which means that the relationship between the variables of Occupational Health and Safety (K3) with the performance of employees of PT. UOB Indonesia Bengkulu Branch relate very strong. Hypothesis testing results, from 14.863 t and t table is 2.0003 or (14.863> 2.0003), then Ho is rejected and Ha accepted means there is a significant relationship between occupational safety and health (K3) with the performance of employees at PT. Branch UOB Indonesia Bengkulu branch.
\end{abstract}

\section{Key Word: Health and Safety(K3), Officer Performance}

\section{PENDAHULUAN}

Persaingan industri yang semakin ketat menuntut perusahaan untuk mengoptimalkan seluruh sumberdaya yang dimiliki dalam menghasilkan produk berkualitas tinggi. Kualitas produk yang dihasilkan tidak terlepas dari peranan sumber daya manusia(SDM) yang dimiliki perusahaan. Faktor-faktor produksi dalam perusahaan seperti modal, mesin, dan material dapat bermanfaat apabila telah diolah oleh SDM. SDM sebagai tenaga kerja tidak terlepas dari masalah-masalah yang berkaitan dengan keselamatan dan kesehatannya sewaktu bekerja.

Riset yang dilakukan badan dunia International Labour Organization (ILO) pada tahun 2003 (ILO dalam Supardi, 2005:3) menghasilkan kesimpulan, setiap hari rata-rata 6.000 orang meninggal, setara dengan satu orang setiap 15 detik atau 2,2 juta orang per tahun akibat sakit atau kecelakaan yang berkaitan dengan pekerjaan mereka. Jumlah pria yang meninggal dua kali lebih banyak dibandingkan wanita, karena mereka lebih mungkin melakukan pekerjaan berbahaya. Secara keseluruhan kecelakaan di tempat kerja telah menewaskan 350.000 orang. Sisanya meninggal karena sakit yang diderita dalam pekerjaan seperti membongkar zat kimia beracun (ILO dalam Supardi, 2005:3).

Keselamatan dan kesehatan kerja harus diupayakan agar tetap kondusif, bahkan meningkat. Hal ini sangat penting karena dapat membuat karyawan merasa aman dan menjadi bersemangat untuk bekerja. Selanjutnya jika karyawan yang sudah merasa keselamatannya terjamin dan bersemangat untuk bekerja, maka diharapkan dengan adanya penerapan keselamatan dan kesehatan kerja yang kondusif, para karyawan akan termotivasi untuk dapat 
bekerja lebih giat dan lebih bersemangat lagi dalam meningkatkan Kinerjanya. Oleh karena itu keselamatan dan kesehatan kerja perlu diperhatikan.

Perusahaan yang baik adalah perusahaan yang benar-benar menjaga keselamatan dan kesehatan karyawannya dengan membuat aturan tentang keselamatan dan kesehatan kerja yang dilaksanakan oleh seluruh karyawan dan pimpinan perusahaan. Perlindungan tenaga kerja dari bahaya dan penyakit akibat kerja atau akibat dari lingkungan kerja sangat dibutuhkan oleh karyawan agar karyawan merasa aman dan nyaman dalam menyelesaikan pekerjaannya. Tenaga kerja yang sehat akan bekerja produktif, sehingga diharapkan produktivitas kerja karyawan meningkat yang dapat mendukung keberhasilan bisnis perusahaan dalam membangun dan membesarkan usahanya.

\section{TINJAUAN LITERATUR Keselamatan dan Kesehatan Kerja (K3)}

Menurut C Meggison yang dikutip oleh Mangkunegara (2000:161) bahwa istilah keselamatan mencakup kedua istilah yaitu resiko keselamatan dan resiko kesehatan. Keselamatan kerja menunjukkan kondisi yang aman atau selamat dari penderitaan, kerusakan atau kerugian ditempat kerja. Resiko keselamatan merupakan aspek aspek dari lingkungan kerja yang dapat menyebabkan kebakaran, ketakutan aliran listrik, terpotong, luka memar, keseleo, patah tulang, kerugian alat tubuh, penglihatan, dan pendengaran. Semua itu sering dihubungan dengan perlengkapan perusahaan atau lingkungan fisik dan mencakup tugas-tugas kerja yang membutuhkan pemeliharaan dan latihan.

Menurut Suma'mur (2001:104) "keselamatan kerja merupakan suatu rangkaian usaha untuk menciptakan suasana kerja yang aman dan tentram bagi para karyawan yang bekerja diperusahaan yang bersangkutan".

Menurut Situmorang (2003:1) keselamatan dan kesehatan kerja dapat dideskripsikan sebagai filosofis dan keilmuan. Secara filosofis yaitu suatu pemikiran atau upaya untuk menjamin keutuhan dan kesempurnaan baik jasmani dan rohaniah tenaga kerja, hasil karya dan budayanya menuju masyarakat yang adil dan makmur. Sedangkan secara keilmuan kesehatan kerja merupakan ilmu pengetahuan dan penerapannya dalam usaha mencegah terjadinya kecelakaan dan penyakit akibat kerja.

\section{Unsur dan Prinsip Keselamatan dan Kesehatan Kerja}

Untuk dapat menciptakan kondisi yang aman dan sehat dalam suatu pekerjaan diperlukanlah unsur-unsur dan prinsip-prinsip keselamatan dan kesehatan kerja. Adapun unsurnya adalah sebagai berikut menurut Sutrisno dan Ruswandi (2007:5):

1. Adanya APD (alat pelindung diri) di tempat kerja.

2. Adanya buku petunjuk penggunaan alat dan atau isyarat bahaya.

3. Adanya peraturan pembagian tugas dan tanggungjawab.

4. Adanya tempat kerja yang sesuai standar SSLK (Syarat-Syarat Lingkungan Kerja) antara lain tempat kerja yang steril dari debu, kotoran, asap rokok, uap gas, radiasi, getaran mesin dan peralatan, kebisingan, tempat kerja aman dari arus listrik, lampu penerangan cukup mamadai, ventilasi dan sirkulasi udara yang nyaman, adanya aturan kerja dan aturan keprilakuan.

5. Adanya penunjang kesehatan jasmani dan rohani di tempat kerja.

6. Adanya sarana dan prasarana yang lengkap ditempat kerja.

7. Adanya kesadaran dalam menjaga keselamatan dan kesehatan kerja.

Menurut Sutrisno dan Ruspuadi (2007:54) prinsip keselamatan dan kesehatan kerja meliputi aspek hiegine, aspek sanitasi, dan aspek lingkungan kerja:

1. Aspek Hiegine meliputi kesehatan dan kebersihan pribadi makanan, minuman, serta pakaian. 
2. Aspek Sanitasi meliputi pengadaan air bersih, pengadaan tempat sampah, merawat dan menyimpan peralatan, serta penataan lingkungan.

3. Aspek lingkungan kerja meliputi mengantisipasi penyebab penyakit maupun kondisi fisik di lingkungan kerja, kondisi kimia, kondisi biologi, dan kondisi psikologi kerja.

\section{Tujuan dan Syarat Keselamatan dan Kesehatan Kerja}

Tujuan Keselamatan dan Kesehatan Kerja pada intinya adalah untuk melindungi pekerja dari kecelakaan akibat kerja. Sutrisno dan Ruswandi (2007:7) mengemukakan bahwa tujuan keselamatan dan kesehatan kerja adalah untuk tercapainya keselamatan karyawan saat bekerja dan setelah bekerja.

Sedangkan Ernawati (2008:70) mengatakan bahwa tujuan keselamatan dan kesehatan kerja adalah:

1. Melindungi dari kemungkinan - kemungkinan buruk yang mungkin terjadi akibat kecerobohan.

2. Memelihara kesehatan untuk memperoleh hasil pekerjaan yang optimal.

3. Mengurangi angka sakit atau angka kematian diantara pekerja.

4. Mencegah timbulnya penyakit menular dan penyakit - penyakit lain yang ditimbulkan oleh sesama pekerja

5. Membina dan meningkatkan kesehatan fisik maupun mental

6. Menjamin keselamatan setiap orang yang berada ditempat kerja

7. Sumber produksi dipelihara dan dipergunakan secara aman dan efisien.

Sedangkan syarat dalam keselamatan dan kesehatan kerja dalam peraturan perundangan No. 1 tahun 1970 Pasal 3 seperti dalam Silalahi (2005:44) adalah sebagai berikut:

1. Mencegah dan mengurangi kecelakaan

2. Mencegah, mengurangi, dan memadamkan kebakaran

3. Mencegah dan mengurangi bahaya peledakan

4. Memberi kesempatan atau jalan menyelamatkan diri pada waktu kebakaran atau kejadian kejadian yang berbahaya

5. Memberi pertolongan pada kecelakaan

6. Memberi alat - alat perlindungan diri pada para pekerja

7. Mencegah dan mengendalikan timbul atau memyebar luasnya suhu, kelembaban, debu, kotoran, asap, uap, gas, dan hembusan angin, cuaca, sinar radiasi, suara dan gertaran

8. Mencegah dan mengendalikan timbulnya penyakit akibat kerja baik fisik maupun psikis, keracunan, infeksi dan penularan.

9. Memperoleh penerangan yang cukup dan sesuai

10. Menyelenggarakan suhu dan lembab udara yang baik

11. Menyelenggarakan kesegaran udara yang cukup

12. Memelihara kesehatan, ketertiban, dan kebersihan

13. Memperoleh keserasian antara tenaga kerja, alat kerja, lingkungan, cara proses kerjanya.

14. Mengamankan dan mempelancar pengangkatan kerja orang, binatang, tanaman atau barang.

Budiono et al (2003:221) mengemukakan indikator Keselamatan dan Kesehatan Kerja (K3), meliputi:

a. Faktor manusia/ pribadi (personal factor) Faktor manusia disini meliputi, antara lain kurangnya kemampuan fisik, mental dan psikologi, kurangnya pengetahuan dan keterampilan/ keahlian, dan stress serta motivasi yang tidak cukup.

b. Faktor kerja/ lingkungan meliputi, tidak cukup kepemimpinan dan pengawasan, rekayasa, pembelian/ pengadaan barang, perawatan, standar-standar kerja dan penyalahgunaan.

Anoraga (2005:22) mengemukakan aspek-aspek Keselamatan dan Kesehatan Kerja (K3) meliputi: 
a. Lingkungan kerja

Lingkungan kerja merupakan tempat dimana seseorang atau karyawan dalam beraktifitas bekerja. Lingkungan kerja dalam hal ini menyangkut kondisi kerja, seperti ventilasi, suhu, penerangan dan situasinya.

b. Alat kerja dan bahan

Alat kerja dan bahan merupakan suatu hal yang pokok dibutuhkan oleh perusahaan untuk memproduksi barang. Dalam memproduksi barang, alat-alat kerja sangatlah vital yang digunakan oleh para pekerja dalam melakukan kegiatan proses produksi dan disamping itu adalah bahan-bahan utama yang akan dijadikan barang.

c. Cara melakukan pekerjaan

Setiap bagian-bagian produksi memiliki cara-cara melakukan pekerjaan yang berbeda-beda yang dimiliki oleh karyawan. Cara-cara yang biasanya dilakukan oleh karyawan dalam melakukan semua aktifitas pekerjaan, misalnya menggunakan peralatan yang sudah tersedia dan pelindung diri secara tepat dan mematuhi peraturan penggunaan peralatan tersebut dan memahami cara mengoperasionalkan mesin.

\section{Kinerja}

Banyak pendapat mengenai kinerja (performance), diantara ahli tersebut memberi pengertian berbeda antara yang satu dengan yang lainnya. Hal ini sesuai dari cara pandang masing-masing para ahli tersebut, namun secara umum pengertian yang dikemukakan masih mempunyai persamaan. Pengertian kinerja menurut Flippo (dalam Rofiatun, 2011) hasil yang dicapai oleh seseorang dalam bidang pekerjaannya menurut kriteria tertentu yang berlaku untuk suatu pekerjaan tertentu dan dievaluasi oleh orang-orang tertentu.

Menurut Hasibuan (2006) menyatakan kinerja adalah suatu hasil kerja yang dicapai seseorang dalam melaksanakan tugas-tugas yang dibebankan kepadanya yang didasarkan atas kecakapan, pengalaman, dan kesungguhan serta waktu.

Sedarmayanti (2010) menjelaskan bahwa kinerja adalah hasil kerja yang dicapai oleh seseorang atau sekelompok orang dalam suatu organisasi, sesuai dengan wewenang dan tanggungjawab masing-masing dalam upaya mencapai tujuan organisasi bersangkutan secara legal, tidak melanggar hukum dan sesuai dengan moral maupun etika.

Mangkunegara (2006) menyatakan kinerja adalah hasil kerja secara kualitas dan kuantitas yang dicapai oleh seseorang karyawan dalam melaksanakan tugasnya sesuai dengan tanggung jawab yang diberikan kepadanya.

Dari semua pengertian tersebut diatas dapat diartikan bahwa kinerja adalah suatu hasil atau taraf kesuksesan yang dicapai oleh karyawan dalam melaksanakan tugasnya sesuai dengan tanggungjawab yang dibebankan kepadanya.

Menurut T.R Mitchell dalam Sedarmayanti (2009) kinerja meliputi beberapa aspek, yaitu:

1. Quality of work (kualitas hasil pekerjaan)

2. $\quad$ Promptness (kecepatan atau ketangkasan)

3. Initiative (inisiatif)

4. Capability (kecakapan)

5. Communication (komunikasi)

Kinerja karyawan mengacu pada prestasi kerja karyawan diukur berdasarkan standard atau criteria yang telah ditetapkan perusahaan. Pengelolaan untuk mencapai kinerja karyawan yang sangat tinggi tertama untuk meningkatkan kinerja perusahaan secara keseluruhan. Dessler (2010) mengatakan ada 6 kategori yang digunakan untuk mengukur kinerja karyawan secara individual, sebagai berikut:

a. Kualitas: akurasi, ketelitian, tingkat dan bias diterima atas pekerjaan yang dilakukan 
b. Produktivitas: kuantitas dan efisiensi kerja yang dihasilkan dalam periode tertentu

c. Pengetahuan pekerjaan: keterampilan dan informasi praktis/teknis yang digunakan dalam pekerjaan

d. Bisa diandalkan (keterpercayaan): sejauhmana karyawan bisa diandalkan atas penyelesaian dan tindak lanjut tugas

e. Kehadiran (ketersediaan): sejauh mana karyawan tepat waktu, mengamati periode istirahat/jam makan yang ditentukan dan catatan kehadiran secara keseluruhan.

f. Kemandirian (kebebasan): sejauh mana pekerjaan yang dilakukan dengan atau tanpa pengawasan.

Menurut Stoner dan Freeman (dalam Sudarmanto, 2012) kinerja dapat diukur melalui kriteria berikut ini:

1. Kuantitas kerja (quantity of work): jumlah kerja yang dilakukan dalam suatu periode

2. Kualitas kerja (quality of work): kualitas kerja yang dicapai berdasarkan syarat-syarat yang ditentukan

3. Kreativitas (creativeness): keaslian gagasan yang dimunculkan dan tindakan-tindakan yang dilakukan untuk menyelesaikan persoalan-persoalan yang muncul

4. Pengetahuan mengenai pekerjaan (knowledge of job): luasnya pengetahuan mengenai pekerjaan dan keterampilan

5. Kerjasama (cooperation): kesediaan untuk bekerjasama dengan orang lain sesame anggota organisasi

6. Inisiatif (initiative): semangat untuk melaksanakan tugas-tugas baru

7. Ketergantungan (dependability): kesadaran dan dapat dipercaya dalam hal kehadiran dalam melaksanakan pekerjaan

8. Kualitas pribadi (personal quality): menyangkut kepribadian, kepemimpinan, keramahan dan integritas pribadi.

Dan beberapa indikator kinerja menurut Schuller dan Jakson (1999) antara lain:

1. Kualitas kerja (mengacu pada akurasi dan margin kesalahan)

2. Kuantitas kerja (mengacu kepada jumlah produksi atau hasil)

3. Ketepatan waktu (mengacu kepada penyelesaian tugas dalam waktu yang sudah ditetapkan)

4. Kehadiran dan ketepatan waktu (mengacu kepada ketepatan dan ketaatan jadwal kerja)

5. Tanggung jawab (mengacu kepada penyelesaian kerja)

6. Kerjasama dengan yang lain (mengacu kepada kerjasama dan komunikasi dengan rekan kerja)

\section{Faktor-faktor yang mempengaruhi kinerja}

Menurut Mahmudi (2005) menjelaskan bahwa faktor-faktor yang mempengaruhi kinerja adalah sebagai berikut:

1. Faktor personal meliputi unsure pengetahuan, ketrampilan, kemampuan, kepercayaan diri, motivasi dan komitmen yang dimiliki oleh setiap individu karyawan.

2. Faktor kepemimpinan meliputi kualitas dalam memberikan dorongan, semangat, arahan dan dukungan yang diberikan manajer team leader.

3. Faktor tim meliputi kualitas dukungan dan semangat yang diberikan oleh rekan dalam satu tim, kepercayaan terhadap sesama anggota tim, kekompakan dan keeratan anggota tim.

4. Faktor sistem meliputi sistem kerja, fasilitas kerja atau infrastruktur yang diberikan oleh organisasi, proses organisasi, dan kultur kerja dalam organisasi 
5. Faktor kontekstual (situasional) meliputi tekanan dan perubahan lingkungan eksternal dan internal.

Adapun menurut Anoraga dan Sayuti (dalam Okta Fariansi, 2010), mengemukakan bahwa faktor-faktor yang mempengaruhi kinerja adalah: motivasi, pendidikan, disiplin, keterampilan, sikap, tingkat penghasilan, lingkungan kerja dan teknologi.

Sedangkan menurut Winardi (dalam Sudarmanto, 2012) mengemukakan bahwa faktorfaktor yang mempengaruhi kinerja dapat dikelompokkan menjadi dua faktor yaitu:

a. Faktor intrinsic meliputi: motivasi, pendidikan, kemampuan, keterampilan, pengetahuan.

b. Faktor ekstrinsik meliputi: lingkungan kerja, kepemimpinan, hubungan kerja, gaji.

Menurut Mangkunegara (2006) faktor-faktor yang mempengaruhi kinerja yaitu:

1. Faktor individu.

Secara psikologis, individu yang normal adalah individu yang memiliki integritas yang tinggin antara fungsi psikis (rohani) dan fisiknya (jasmaniah). Adanya integritas yang tinggi antara fungsi psikis dan fisik maka individu tersebut memiliki konsentrasi diri yang baik. Konsentrasi yang baik ini merupakan modal utama individu manusia untuk mampu mengelola dan mendayagunakan potensi dirinya secara optimal dalam melaksanakan kegiatan atau aktivitas kerja sehari-hari dalam mencapai tujuan organisasi.

2. Faktor lingkungan organisasi.

Faktor lingkungan kerja organisasi sangat menunjang bagi individu dalam mencapai kinerja. Faktor lingkungan organisasi yang dimaksud antara lain uraian jabatan yang jelas, otoritas yang memadai, target kerja yang menantang, pola komunikasi yang efektif, hubungan kerja yang harmonis, iklim kerja yang respek dan dinamis, peluang berkarir dan fasilitas.

\section{KERANGKA ANALISIS}

\begin{tabular}{|c|c|}
\hline $\begin{array}{l}\text { Keselamatan dan KesehatanKerja (K3) } \\
\quad \text { Lingkungan kerja } \\
\text { Alat kerja } \\
\text { Bahan dan cara melakukan } \\
\text { pekerjaan } \\
\text { Bahan dan cara melakukan } \\
\text { pekerjaan }\end{array}$ & $\begin{array}{l}\text { Kinerja } \\
\text { - Kualitas } \\
\text { - Produktivitas } \\
\text { - Pengetahuan pekerjaan } \\
\text { - Keterpercayaan } \\
\text { - Kehadiran }\end{array}$ \\
\hline
\end{tabular}

Gambar 1. Kerangka Analisis

\section{HASIL PENELITIAN DAN PEMBAHASAN}

Untuk mengetahui hubungan antarakeselamatan dan kesehatan kerja (K3) dengan Kinerja karyawan pada PT. UOB Indonesia Cabang Bengkulu, maka digunakan analisis deskriftif kualitatif dan kuantitatif.

Dari hasil penyebaran kuisioner kepada responden maka diperoleh data skor jawaban responden tentang variabel Keselamatan dan Kesehatan Kerja (X) dan Kinerja $(\mathrm{Y})$ dianalisis kedalam perhitungan berikut ini: 
Tabel 1. Distribusi Rata-Rata Persepsi Responden Terhadap Variabel Keselamatan dan Kesehatan Kerja (K3) (X)

\begin{tabular}{|c|c|c|c|c|c|c|c|c|}
\hline \multirow{2}{*}{ Pernyataan } & \multicolumn{5}{|c|}{ Tanggapan Responden } & \multirow{2}{*}{ Jumlah } & \multirow{2}{*}{$\begin{array}{l}\text { Rata- } \\
\text { Rata }\end{array}$} & \multirow{2}{*}{ Kriteria } \\
\hline & SS & $S$ & CS & TS & STS & & & \\
\hline Kondisi fisik bangunan kantor yang layak & - & 46 & 14 & - & - & 226 & 3,77 & Baik \\
\hline Ketersediaan fasilitas pendukung pekerjaan & 1 & 44 & 15 & - & - & 226 & 3,77 & Baik \\
\hline $\begin{array}{l}\text { Lingkungan kerja yang nyaman dari gangguan } \\
\text { suara yang menimbulkan kebisingan }\end{array}$ & - & 41 & 19 & - & - & 221 & 3,68 & Baik \\
\hline $\begin{array}{lcccc}\text { Sirkulasi udara ruangan kerja saya dapat } \\
\text { menimbulkan rasa nyaman }\end{array}$ & 9 & 33 & 18 & - & - & 231 & 3,85 & Baik \\
\hline $\begin{array}{l}\text { Peralatan yang digunakan dalam bekerja tidak } \\
\text { dalam keadaan rusak. }\end{array}$ & 8 & 35 & 17 & - & - & 231 & 3,85 & baik \\
\hline $\begin{array}{l}\text { Peralatan telah sesuai dengan Standar Negara } \\
\text { Indonesi(SNI) }\end{array}$ & 12 & 27 & 21 & - & - & 231 & 3,85 & Baik \\
\hline $\begin{array}{l}\text { Peralatan dan bahan-bahan yang digunakan dalam } \\
\text { bekerja tidak membahayakan karyawan. }\end{array}$ & 6 & 35 & 19 & - & - & 227 & 3,78 & Baik \\
\hline $\begin{array}{l}\text { Karyawan memiliki istirahat yang cukup untuk } \\
\text { memulihkan stamina sehabis bekerja }\end{array}$ & 1 & 34 & 25 & - & - & 216 & 3,60 & Baik \\
\hline $\begin{array}{l}\text { Karyawan melakukan pekerjaan dengan berhati- } \\
\text { hati dan mengikuti standar yang ada. }\end{array}$ & 12 & 29 & 19 & - & - & 233 & 3,88 & Baik \\
\hline $\begin{array}{l}\text { Karyawan PT. UOB Indonesia memiliki peraturan } \\
\text { untuk memberikan laporan seara berkala } \\
\text { mengenai kondisi peralatan dan kesehatan setiap } \\
\text { karyawan. }\end{array}$ & 7 & 36 & 17 & - & - & 230 & 3,83 & Baik \\
\hline Rata-rata & & & & & & & 3,79 & Baik \\
\hline
\end{tabular}

Sumber: Hasil Penelitian, diolah 2014

Dari tabel1 di atas dapat di lihatrata-ratapersepsi responden terhadap variabel keselamatan dan kesehatan kerja (X) pada rata-rata 3,79 termasuk dalam interval 3,41-4,20 yaitu dengan kriteria baik, artinya dalam penerapan keselamatan dan kesehatan kerja (K3) pada PT. UOB Indonesia Cabang Bengkulu dalam kondisi yang baik.

Pada tabel 1 di atas juga dapat dilihat bahwa pernyataan "Karyawan melakukan pekerjaan dengan berhati-hati dan mengikuti standar yang ada" mendapatkan skor jawaban tertinggi dari responden yaitu 3,88 dan pernyataan "Lingkungan kerja yang nyaman dari gangguan suara yang menimbulkan kebisinganmendapatkan skor jawaban terendah dari responden yaitu 3,68 .

Tabel 2. Distribusi Rata-Rata Persepsi Responden Terhadap Variabel Kinerja Karyawan (Y)

\begin{tabular}{|c|c|c|c|c|c|c|c|c|}
\hline \multirow{2}{*}{ Pernyataan } & \multicolumn{5}{|c|}{ Tanggapan Responden } & \multirow{2}{*}{ Jumlah } & \multirow{2}{*}{$\begin{array}{l}\text { Rata- } \\
\text { Rata }\end{array}$} & \multirow{2}{*}{ Kriteria } \\
\hline & SS & $S$ & $\mathrm{CS}$ & TS & STS & & & \\
\hline $\begin{array}{l}\text { Karyawan memahami bahwa setiap pekerjaan yang } \\
\text { harus dilakukan dibutuhkan ketelitian }\end{array}$ & - & 46 & 14 & - & - & 227 & 3,77 & Baik \\
\hline $\begin{array}{l}\text { Hasil kerja karyawan berkualitas sesuai prosedur } \\
\text { yang ditentukan }\end{array}$ & - & 45 & 15 & - & - & 227 & 3,75 & Baik \\
\hline $\begin{array}{l}\text { Pekerjaan yang dilakukan selesai sebelum waktu } \\
\text { yang ditentukan }\end{array}$ & - & 41 & 19 & - & - & 224 & 3,68 & Baik \\
\hline $\begin{array}{l}\text { Karyawan mengetahui prosedur pekerjaan yang } \\
\text { dibuat diperusahaan }\end{array}$ & 9 & 33 & 18 & - & - & 235 & 3,85 & Baik \\
\hline $\begin{array}{l}\text { Karyawan mengetahui secara teknis pekerjaan yang } \\
\text { harus diselesaikan }\end{array}$ & 9 & 36 & 15 & - & - & 239 & 3,90 & Baik \\
\hline $\begin{array}{l}\text { Karyawan memberikan hasil yang maksimal dalam } \\
\text { pekerjaan }\end{array}$ & 12 & 27 & 21 & - & - & 237 & 3,85 & baik \\
\hline $\begin{array}{l}\text { Melakukan pekerjaan dengan baik sesuai keahlian } \\
\text { yang dimiliki }\end{array}$ & 7 & 35 & 18 & - & - & 236 & 3,82 & Baik \\
\hline $\begin{array}{l}\text { Karyawan selalu berusaha untuk hadir tepat waktu } \\
\text { dalam bekerja }\end{array}$ & 1 & 34 & 25 & - & - & 224 & 3,60 & Baik \\
\hline $\begin{array}{l}\text { Memiliki intensitas kehadiran yang baik sesuai } \\
\text { dengan tata tertib perusahaan }\end{array}$ & 12 & 29 & 19 & - & - & 242 & 3,88 & Baik \\
\hline $\begin{array}{l}\text { Melakukan pekerjaan dengan baik tanpa pengawasan } \\
\text { maupun dengan pengawasan }\end{array}$ & 8 & 37 & 15 & - & - & 243 & 3,88 & Baik \\
\hline Rata-rata & & & & & & & 3,80 & Baik \\
\hline
\end{tabular}

Sumber: Hasil Penelitian, diolah 2014 
Dari tabel 2 di atas terlihat rata-rata persepsi responden terhadap variabel Kinerja $(\mathrm{Y})$ sebesar 3,80 nilai tersebut terletak pada interval 3,41-4,20 dengan kategori baik, artinya Kinerja pegawai pada PT. UOB Bengkulu adalah baik. Hal ini menunjukkan bahwa seluruh karyawan PT. UOB Indonesia Cabang Bengkulu memiliki prestasi yang cukup tinggi dalam bekerja pada PT. UOB Indonesia Cabang Bengkulu.

Untuk variabel kinerja jawaban skor tertinggi adalah jawaban responden pada pernyataan "Karyawan mengetahui secara teknis pekerjaan yang harus diselesaikan" yaitu dengan rata-rata 3,90 dalam keadaan baik, sedangkan skor terendah pada pernyataan "Karyawan selalu berusaha untuk hadir tepat waktu dalam bekerja" dengan nilai rata-rata 3.60.

\section{Analisis Korelasi Spearman Rank}

Untuk dapat menghitung dan menganalisis korelasi spearman rank maka harus diketahui terlebih dahulu nilai $\sum \mathrm{bi}^{2}$. Perbandingan rank nilai keselamatan dan kesehatan kerja (K3) dan Kinerja karyawan pada PT. UOB Indonesia Cabang Bengkulu yang diformulasikan pada tabel berikut ini :

Tabel 3. Perbandingan rank nilai keselamatan dan kesehatan kerja (K3) dan Kinerjakaryawan pada PT. UOB Indonesia Cabang Bengkulu

\begin{tabular}{|c|c|c|c|c|c|c|}
\hline $\begin{array}{c}\text { No } \\
\text { Responden } \\
\end{array}$ & $\begin{array}{c}\text { Skor } \\
\text { Variabel X } \\
\end{array}$ & $\begin{array}{c}\text { Skor } \\
\text { Variabel Y } \\
\end{array}$ & $\begin{array}{l}\text { Hasil Rangking } \\
\text { Skor variabel X }\end{array}$ & $\begin{array}{l}\text { Hasil Rangking } \\
\text { Skor variabel Y }\end{array}$ & bi & bi $^{2}$ \\
\hline 1 & 34 & 39 & 59,5 & 17 & 42,5 & 1806,25 \\
\hline 2 & 35 & 35 & 57 & 58 & -1 & 1 \\
\hline 3 & 34 & 34 & 59,5 & 60 & $-0,5$ & 0,25 \\
\hline 4 & 36 & 36 & 53 & 54 & -1 & 1 \\
\hline 5 & 38 & 38 & 27,5 & 29 & $-1,5$ & 2,25 \\
\hline 6 & 38 & 37 & 27,5 & 44 & $-16,5$ & 272,25 \\
\hline 7 & 39 & 39 & 15 & 17 & -2 & 4 \\
\hline 8 & 37 & 37 & 43,5 & 44 & $-0,5$ & 0,25 \\
\hline 9 & 36 & 36 & 53 & 54 & -1 & 1 \\
\hline 10 & 38 & 37 & 27,5 & 44 & $-16,5$ & 272,25 \\
\hline 11 & 38 & 38 & 27,5 & 29 & $-1,5$ & 2,25 \\
\hline 12 & 39 & 39 & 15 & 17 & -2 & 4 \\
\hline 13 & 40 & 40 & 7,5 & 8 & $-0,5$ & 0,25 \\
\hline 14 & 40 & 40 & 7,5 & 8 & $-0,5$ & 0,25 \\
\hline 15 & 38 & 38 & 27,5 & 29 & $-1,5$ & 2,25 \\
\hline 16 & 38 & 39 & 27,5 & 17 & 10,5 & 110,25 \\
\hline 17 & 40 & 40 & 7,5 & 8 & $-0,5$ & 0,25 \\
\hline 18 & 42 & 42 & 1 & 1 & 0 & 0 \\
\hline 19 & 41 & 41 & 2,5 & 2,5 & 0 & 0 \\
\hline 20 & 38 & 38 & 27,5 & 29 & $-1,5$ & 2,25 \\
\hline 21 & 39 & 39 & 15 & 17 & -2 & 4 \\
\hline 22 & 39 & 39 & 15 & 17 & -2 & 4 \\
\hline 23 & 36 & 36 & 53 & 54 & -1 & 1 \\
\hline 24 & 37 & 40 & 43,5 & 8 & 35,5 & 1260,25 \\
\hline 25 & 40 & 40 & 7,5 & 8 & $-0,5$ & 0,25 \\
\hline 26 & 37 & 37 & 43,5 & 44 & $-0,5$ & 0,25 \\
\hline 27 & 37 & 37 & 43,5 & 44 & $-0,5$ & 0,25 \\
\hline 28 & 37 & 37 & 43,5 & 44 & $-0,5$ & 0,25 \\
\hline 29 & 38 & 38 & 27,5 & 29 & $-1,5$ & 2,25 \\
\hline 30 & 39 & 39 & 15 & 17 & -2 & 4 \\
\hline 31 & 37 & 37 & 43,5 & 44 & $-0,5$ & 0,25 \\
\hline 32 & 37 & 37 & 43,5 & 44 & $-0,5$ & 0,25 \\
\hline 33 & 38 & 38 & 27,5 & 29 & $-1,5$ & 2,25 \\
\hline 34 & 38 & 38 & 27,5 & 29 & $-1,5$ & 2,25 \\
\hline 35 & 36 & 36 & 53 & 54 & -1 & 1 \\
\hline 36 & 38 & 38 & 27,5 & 29 & $-1,5$ & 2,25 \\
\hline 37 & 38 & 38 & 27,5 & 29 & $-1,5$ & 2,25 \\
\hline 38 & 37 & 37 & 43,5 & 44 & $-0,5$ & 0,25 \\
\hline
\end{tabular}




\begin{tabular}{|c|c|c|c|c|c|c|}
\hline $\begin{array}{c}\text { No } \\
\text { Responden }\end{array}$ & $\begin{array}{c}\text { Skor } \\
\text { Variabel X }\end{array}$ & $\begin{array}{c}\text { Skor } \\
\text { Variabel Y }\end{array}$ & $\begin{array}{c}\text { Hasil Rangking } \\
\text { Skor variabel X }\end{array}$ & $\begin{array}{c}\text { Hasil Rangking } \\
\text { Skor variabel Y }\end{array}$ & bi & bi $^{\mathbf{2}}$ \\
\hline 39 & 38 & 38 & 27,5 & 29 & $-1,5$ & 2,25 \\
\hline 40 & 40 & 40 & 7,5 & 8 & $-0,5$ & 0,25 \\
\hline 41 & 41 & 41 & 2,5 & 2,5 & 0 & 0 \\
\hline 42 & 38 & 38 & 27,5 & 29 & $-1,5$ & 2,25 \\
\hline 43 & 38 & 38 & 27,5 & 29 & $-1,5$ & 2,25 \\
\hline 44 & 40 & 40 & 7,5 & 8 & $-0,5$ & 0,25 \\
\hline 45 & 36 & 36 & 53 & 54 & -1 & 1 \\
\hline 46 & 37 & 37 & 43,5 & 44 & $-0,5$ & 0,25 \\
\hline 47 & 39 & 39 & 15 & 17 & -2 & 4 \\
\hline 48 & 40 & 40 & 7,5 & 8 & $-0,5$ & 0,25 \\
\hline 49 & 35 & 35 & 57 & 58 & -1 & 1 \\
\hline 50 & 37 & 37 & 43,5 & 44 & $-0,5$ & 0,25 \\
\hline 51 & 39 & 39 & 15 & 17 & -2 & 4 \\
\hline 52 & 37 & 37 & 43,5 & 44 & $-0,5$ & 0,25 \\
\hline 53 & 35 & 35 & 57 & 58 & -1 & 1 \\
\hline 54 & 37 & 37 & 43,5 & 44 & $-0,5$ & 0,25 \\
\hline 55 & 40 & 40 & 7,5 & 8 & $-0,5$ & 0,25 \\
\hline 56 & 37 & 37 & 43,5 & 44 & $-0,5$ & 0,25 \\
\hline 57 & 37 & 37 & 43,5 & 44 & $-0,5$ & 0,25 \\
\hline 58 & 38 & 38 & 27,5 & 29 & $-1,5$ & 2,25 \\
\hline 59 & 38 & 38 & 27,5 & 29 & $-1,5$ & 2,25 \\
\hline 60 & 38 & 38 & 27,5 & 29 & $-1,5$ & 2,25 \\
\hline & 2272 & 2279 & 1830 & 1830 & 0 & 3796,5 \\
\hline
\end{tabular}

Sumber: Hasil Penelitian, diolah 2014

Setelah nilai $\sum$ bi $^{2}$ diketahui maka dapat dihitung nilai $\rho$ (koefisien korelasi spearman) sebagai berikut :

Diketahui :
$\sum \mathrm{bi}^{2}=3796,5$
$\mathrm{n} \quad=60$

Sehingga nilai $\rho$ (koefisien korelasi spearman) dapat di hitung dengan rumus sebagai berikut :

$$
\begin{aligned}
& \rho=1-\frac{6 \sum b_{i}^{2}}{n\left(n^{2}-1\right)} \\
& \rho=1-\frac{6 \times 3796,5}{60\left(60^{2}-1\right)} \\
& \rho=1-\frac{22779}{60(3600-1)} \\
& \rho=1-\frac{22779}{60 \times 3599} \\
& \rho=1-\frac{22779}{215940} \\
& \rho=1-0,11 \\
& \rho=0,89
\end{aligned}
$$

Tabel 4 : Interpretasi korelasi

\begin{tabular}{|c|c|}
\hline Interval Koefisien & Tingkat Hubungan \\
\hline $0.00-0.199$ & Sangat Rendah \\
\hline $0.20-0.399$ & Rendah \\
\hline $0.40-0.599$ & Sedang \\
\hline $0.60-0.799$ & Kuat \\
\hline $0.80-1.000$ & Sangat Kuat \\
\hline
\end{tabular}

Sumber : Sugiyono (2009:250). 
Berdasarkan hasil perhitungan nilai $\rho$ (koefisien korelasi spearman) dan tabel interprestasi korelasi di atas diketahui bahwa nilai $\rho=0,89$. Nilai tersebut berada pada interval $0,80-1,000$ yaitu sangat kuat, artinya hubungan antara variabel keselamatan dan kesehatan kerja (K3) dengan Kinerja karyawan PT. UOB Indonesia Cabang Bengkulu adalah positif dan sangat kuat, dengan adanya keselamatan dan kesehatan kerja (K3) di PT. UOB Indonesia Cabang Bengkulu maka dapat meningkatkan Kinerja para karyawan yang ada.

\section{Uji Hipotesis}

Uji hipotesisbertujuan untuk mengetahui bagaimana signifikasi hubungan variabel keselamatan dan kesehatan kerja (K3) dengan Kinerja karyawan PT. UOB Indonesia Cabang Bengkulu. Pada penelitian ini tingkat keyakinan $95 \%(\alpha=0,05)$, dengan hipotesis sebagai berikut :

Ho : Tidak terdapat hubungan antara keselamatan dan kesehatan kerja (K3) dengan Kinerja karyawan PT. UOB Indonesia cabang Bengkulu.

Ha : Terdapat hubungan antara keselamatan dan kesehatan kerja (K3) dengan Kinerja karyawan PT. UOB Indonesia cabang Bengkulu.

Dengan kriteria pengujian hipotesis sebagai berikut :

a. Jika $t$ hitung lebih besar dari $t$ tabel maka Ho ditolak dan Ha diterima berarti ada hubungan yang signifikan antara keselamatan dan kesehatan kerja (K3) dengan Kinerja karyawan pada PT. UOB Indonesia Cabang Bengkulu.

b. Jika $t$ hitung lebih kecil dari $t$ tabel maka Ho diterima dan Ha ditolak berarti tidak ada hubungan yang signifikan antara keselamatan dan kesehatan kerja (K3) dengan Kinerja karyawan pada PT. UOB Indonesia Cabang Bengkulu

Adapun hasil perhitungannya adalah sebagai berikut:

$$
\begin{aligned}
& \mathrm{t}_{\text {hitung }}=\mathrm{rs} \sqrt{\frac{n-2}{1-r s^{2}}} \text { (Sugiyono, 2009:315) } \\
& t=0,89 \sqrt{\frac{60-2}{1-0,89^{2}}} \\
& t=0,89 \sqrt{\frac{58}{1-0,7921}} \\
& t=0,89 \sqrt{\frac{58}{0,2079}} \\
& t=0,89 \sqrt{278,98} \\
& t=0,89 \times 16,70 \\
& t=14,863
\end{aligned}
$$

Dari hasil perhitungan di atas maka di dapat hasil t hitung adalah 14,863 dan lebih besar daripada t tabel yaitu 2.00030, maka Ho ditolak dan Ha Diterima berarti ada hubungan yang signifikan antara keselamatan dan kesehatan kerja (K3) dengan Kinerja karyawan pada PT. UOB Indonesia Cabang Bengkulu.

\section{KESIMPULAN}

1. Persepsi responden terhadap keseluruhan pernyataan terhadap variabel keselamatan dan kesehatan kerja (K3) rata-rata sebesar 3,79 atau pada interval range 3,41-4,20 dengan kategori baik dan Persepsi responden terhadap variabel Kinerja rata-rata sebesar 3,80. Nilai tersebut berada pada interval 3,41-4,20 dengan kategori baik. 
2. Dari analisis rank spearman diperoleh nilai koefisien korelasi atau rho hitung sebesar 0,89 berada pada 0,80 - 1,000 yaitu sangat kuat, artinya hubungan antara variabel keselamatan dan kesehatan kerja (K3) dengan Kinerja karyawan PT. UOB Indonesia berhubungan sangat kuat.

3. Dari uji hipotesis, $t$ hitung sebesar 14,863 dan $t$ tabel yaitu 2,0003 atau $(14,863>2,0003)$, maka Ho ditolak dan Ha diterima artinya terdapat hubungan yang signifikan antara keselamatan dan kesehatan kerja (K3) dengan Kinerja karyawan pada PT. UOB Indonesia Cabang Bengkulu.

\section{SARAN}

Mengingat keselamatan dan kesehatan kerja (K3) mempunyai hubungan terhadap Kinerja karyawan, maka diharapkan PT. UOB Indonesia Cabang Bengkulu hendaknya melakukan perbaikan dan peningkatan terhadap program K3 yang meliputi lingkungan kerja, alat kerja dan bahan yang digunakan dalam bekerja serta cara dan standar melakukan pekerjaan sehingga karyawan merasa aman dan nyaman dalam bekerja.

\section{DAFTAR PUSTAKA}

Anoraga, Panji. 2005. Psikologi Kerja, Jakarta: PT. Rineka Cipta

Budiono et al. 2003. Bunga Rampai Hiperkes dan Keselamatan Kerja, Semarang: Badan Penerbit Universitas Diponegoro

Dessler, G. 2010. Manajemen Personalia Edisi 3. Terjemahan Agus Dharma. Jakarta: Penerbit Erlangga.

Ernawati. 2008. Tata Busana Jilid 1 untuk Sekolah Menengah Kejuruan. Jakarta: Direktorat Pembinaan Sekolah Menengah Kejuruan

Fariansi, Okta. 2010. Pengaruh Motivasi, Disiplin dan Lingkungan Kerja Terhadap Kinerja Karyawan Marketting Account Officer PT.BPRS Syafir Bengkulu. Universitas Bengkulu

Hasibuan, Malayu, S.P. 2003. Manajemen Dasar, Pengertian dan. Masalah. Jakarta: PT Toko Gunung Agung.

Hasibuan. 2006. Manajemen Sumber Daya Manusia. Jakarta: PT. Bumi Aksara.

Ichsan. 2001. Kesehatan Lingkungan. Jakarta: Dekdikbud

Mahmudi. 2005. Manajemen Kinerja Sektor Publik. Yogyakarta: UPP AMP YKPN.

Mangkunegara, Anwar Prabu. 2000. Manajemen Sumber Daya Manusia Perusahaan. Bandung: PT Remaja Rosdakarya

Mangkunegara, A. Anwar Prabu. 2006. Evaluasi Kinerja SDM. Cetakan kedua. Bandung: PT. Refika Aditama.

Moenir, A.S. 2003. Manajemen Pelayanan Umum di Indonesia. Jakarta: Bumi Aksara

Rofiatun dan Masluri. 2011. Pengaruh Iklim Organisasi dan Kompetensi Pegawai terhadap Kinerja Pegawai dengan Mediasi Motivasi pada Dinas-dinas di Kabupaten Kudus. Jurnal Analisis Manajemen, Vol.5, No.1. 
Sari, Irine Diana. 2008. Manajemen Pemasaran Usaha kesehatan. Yogyakarta: Mitra Cendikia

Schuller, dan Jackson. 1999. Manajemen Sumber Daya Manusia Produktif. Jakarta: Gema Insani Press.

Sedarmayanti. 2009. Sumber Daya Manusia dan Produktivitas Kerja. Bandung: CV. Mandar Maju.

Sedarmayanti. 2010. Pengembangan Kepribadian Pegawai. Bandung: CV.Mandar Maju.

Silalahi, Bennet dan Silalahi, Rumondang. 2005. Seri Manajemen Keselamatan dan Kesehatan Kerja. Jakarta: PT Pustaka Binaman Pressindo

Singarimbun, Masri dan Sofyan Effendi. 1999. Metode Penelitian Survey. Jakarta: LP3ES.

Situmorang, Chaidir. 2003. Mengikuti prosedur keselamatan dan kesehatan kerja Jakarta: Depdiknas. Direktorat Pendidikan Menengah Kejuruan

Sudarmanto. 2012. Pengaruh Motivasi dan Disiplin Kerja Terhadap Kinerja Pegawai Bagian Umum dan Protokol di Sekretariat Daerah Pemerintah Kota Bengkulu. Bengkulu. Universitas Bengkulu.

Sugiyono. 2009. Metode Penelitian Bisnis. Bandung: Alfabeta

Suma'mur P.K. 2001, Keselamatan Kerja dan Pencegahan Kecelakaan,. PT. Toko Gunung Agung: Jakarta

Supardi. 2005. Metode Penelitian Ekonomi dan Bisnis. Yogyakarta: UII Press

Sutrisno dan Kusmawan Ruswandi. 2007. Prosedur Keamanan, Keselamatan, \& Kesehatan Kerja. Sukabumi: Yudhistira.

Sutrisno, Edy. 2009, Manajemen Sumber Daya Manusia. Jakarta: Kencana

Syafei, Buyung. 2009. Sekali Lagi Tentang Sistem Perekonomian, (http://deroe.wordpress.com/2009/02/13/sekali lagitentangsistemperekonomian) 